\title{
Athens or Jerusalem?
}

\section{Puntel on Levinas}

\author{
Jack Marsh \\ University of St. Andrews, Divinity School, St. Andrews, U K \\ jmarshjı@binghamton.edu
}

Puntel, Lorenz. Being and God: A Systematic Approach in Confrontation with Martin Heidegger, Emmanuel Levinas, and Jean-Luc Marion, Trans. White, Alan. Evanston, Northwestern University Press.

When I selected this book for review, I was utterly unaware of what I was getting myself into. ${ }^{1}$ Puntel has produced a full-fledged ontology constructed in a meticulously argued dialogue with major philosophical voices on both sides of the Atlantic. When Tarski, Carnap, and Quine converse with Heidegger, Kant, and Aquinas, and in the midst of a serious and systematic treatment of the question of "Being as such and as a whole," (3) something quite unusual is taking place. As Puntel's project unfolds in this book, it becomes clear he is not engaged in a vague or eclectic philosophical syncretism. Instead, Puntel performs an audacious, highly original, and philosophically autonomous resurrection of metaphysics. Needless to say, it will be impossible for me to do justice to Puntel's central arguments in this 40o-page tome in the short space allotted me here. This book is a veritable philosophical achievement that warrants wide critical consideration. Despite my great admiration, I remain largely critical of Puntel's general project guided by the question of the justice of his treatment Levinas's work. Though Puntel succeeds in underlining at least one genuine problem in Levinas' work, his overall treatment of Levinas is not serious and amounts to purely external criticism. Indeed, since the subtitle of the book reads "A Systematic Approach in Confrontation with Martin Heidegger, Emmanuel Levinas, and Jean-Luc Marion," one would expect Levinas and Marion to receive substantial treatment. As it turns out, Puntel's critical treatment of Levinas composes a total of 19 of the book's 419 pages. It is clear early

1 I wrote this review essay in Fall, 2011 for Cahiers d'études lévinassiennes but it was not published due to length. 
on that Puntel's true aim is to showcase his own ontology and to bring it to bear on the question of God. There is certainly nothing wrong with that per se, but the book's title should more thoroughly reflect it and not give the misleading impression that Levinas is genuinely confronted. He is not, as we are about to see.

At the outset, Puntel stresses his project's strictly theoretical orientation. He is not out to 'defend the faith,' convert us, help us live better lives, or even convince us of the rationality of theism. Instead, "The specific goal of this book is ... [to present] a philosophical framework within which ... a theory [of God] could be developed" (4). Before turning to this specific task, Puntel conducts a series of critical encounters with other approaches to the questions of God and Being. Chapter 1 treats and criticizes what Puntel calls "unsystematic," "partially systematic," and "antisystematic" approaches to the question of God. Chapter 2 conducts an interesting and controversial reading of Heidegger. Puntel credits Heidegger with radically posing the question of being in a new and fundamental way, but judges Heidegger's own form of thinking to be ultimately deficient. Heidegger's opening of the so-called 'ontological difference' - the difference between Being and beings - is absolutely central to Puntel's project, as we will see briefly below. Chapters 1 and 2 function to distinguish Puntel's own approach from other approaches both traditional and contemporary, and as such clears the ground for his own properly original proposal. Chapter 3 finally takes up the books stated aim of clarifying the framework in which a theory of God' can or should be developed. After conducting this clarification, Puntel critically engages classical (Christian) theism and judges it a promising but ultimately inadequate philosophical approach to God, and then finally turns to his own proposal. With this proposal in hand, he finally turns to a critical treatment of Marion and Levinas' "deep confusion[s]" (287) on the question of God and Being.

Puntel's ontology is genuinely original. So as to not misrepresent his arguments vis-à-vis God, I will very briefly sketch its broad outlines. Puntel essentially reconstructs Hegel's contention that 'what is real is rational and what is rational is real' using the resources of analytic philosophy, while attempting to shed Hegel's subjectivism by appropriating Heidegger's es gibt. The hinge of this reconstruction is his rejection of compositional theories of truth. Puntel underlines Wittgenstein's Tractatus: "The world is the totality of facts, not of things" (178). There is no indeterminate ' $x$ ' that attends our judgments about the world. Facts are real and describable. The initial 'data' the philosopher considers are "prime sentences" such as 'it is the case that snow is white.' If snow is in fact white, the proposition 'snow is white' is true and has ontological import. We can thus begin with relatively simple prime facts, and through a process 
of progressively more thorough theoretical specification, arrive at increasingly more general levels of theoretical determination. In these ascending levels of determination, we can consider and systematically situate or 'configure' various facts and the theories that realize them into overarching domains of coherent relatedness, or higher-order theories and the meanings they specify. The terminus of this process is "the configuration of all configurations" (191), or what Puntel calls: "Being as such and as a whole." According to Puntel, Being so construed is neither a formal effect of the logic of theory, nor merely posited by the philosopher. It rather is the concrete and necessary presupposition for theory in general, and hence the proper topic of philosophy as such. This dimension of "primordial Being" (181) heralds itself in the very form of the indicative sentence: in the 'it' of 'it is the case that .... Puntel follows Heidegger in holding that the 'it' gives meaning, but vigorously rejects Heidegger's mysticism. With the 'it,' Being as such signals itself as the "configuration of all configurations" or "the unrestricted universe of discourse" (181). With Heidegger, this universal dimension cannot unambiguously occupy either the subject or object position in the standard grammar of sentences. Being is the meaning that allows us to consider beings, and hence is not $a$ being. Being precedes and makes possible the division of beings into subject and object, and hence it's meaning is already operative in the distinction between human beings and their world. If the 'it' in 'it is the case that ...' signals Being as such, the 'is' signals Being's meaning as a whole. The 'is' in 'it is the case that ...' signals that Being itself determines itself as the wholly encompassing context of both 'subjective' or human beings and 'objective' beings, such as snow, scotch, or the Milky Way. As such, all subjects and objects that occupy the standard grammar of sentences ultimately signify as Being's own self-determinations, or in other words, their meaning is reducible to what's expressed in realized indicative sentences with the above form. Puntel writes:

The subject term is itself just such a complex configuration. This state of affairs is clarified by consideration of the subject-predicate sentence "Socrates is a philosopher." Following Quine, one could verbalize the name "Socrates" and formulate the prime sentence "It's Socratesing." Among the prime sentences included within the complex configuration "It's Socratesing" are "It's Being-Greek" and "It's Being-born-in-469-BC." What the subject-predicate sentence "Socrates is a philosopher" abbreviates can thus be formulated as follows: There is a configuration "It's Socratesing" consisting of the prime sentences ..., such that among these prime sentences is "It's Being-a-philosopher" (or: "It's philosophering"). 
As Puntel makes clear: Being itself discloses itself as universally (i) intelligible, (ii) expressible, but also as (iii) good (215-217). Puntel never actually argues for or concretely shows how being signifies itself as good, since that is not his primary aim in this book. At this point, Puntel turns to specify the precise way in which Being determines itself as a whole, hence illuminating the concrete difference between Being and beings, and therefore specifying the precise meaning of the 'is' in 'it is the case that ...' Puntel argues the Being itself modalizes itself, or divides itself into 'necessary' and 'contingent' dimensions (219-230). Necessary Being is Being as such. Contingent being is the domain of beings and the lower-order structural determinations that realize them. With Necessary Being so construed, Puntel has approached the word 'God.' He goes on to claim, in a series of interesting arguments, that Necessary Being is necessarily Minded, or possesses "intelligence, will, [and] freedom," and is hence "personal" (233). Moreover, Being's modalization occurs in its capacity for absolute creation (231-235): Being as such creates its own contingent dimension, or in other words: creates the world. This creation does not proceed causally, but as a "positing-within-Being ex nihilo sui et subiecti, out of the non-being of what is posited and of anything from which what is posited could in any way be produced" (389). So construed, Necessary Being is "Therefore ... God" (252). God is Being as such and as a whole, the concrete meaning that signals itself in the most every day indicative sentences of the form 'it is the case that ...' The difference between God and beings - between God and rain, human beings, comets, or whatever else - lies in God's unique capacity to create out of nothing and God's unique status as the ultimate ground on which contingent beings depend for their being.

My description of Puntel's ontology and its move vis-à-vis God is, for reasons of space, severely condensed. In spite of the critical remarks that follow, we should note that each step in Puntel's path is meticulously argued. Puntel's proposal is genuinely original and warrants slow, careful, and sustained attention. Undoubtedly, Puntel is going to draw intense fire from many philosophical quarters on both sides of the Atlantic. Given Puntel's method and the God he has procured himself, it is not surprising that Levinas comes under fire. Puntel's entire edifice is premised on effacing a distinction central to Levinas and much contemporary philosophy; namely, the distinction between thought and life. This is especially clear in Puntel's treatment of Levinas.

Puntel levels four basic criticisms: Levinas has a (1) "misguided" conception of knowledge and theory (285-288), (2) "incoherent" account of metaphysics (288-291), (3) "fatal misconception" of Being and beings (291-294), and (4) "misguided conceptions of transcendence," Infinity, and creation (294- 
302). Informed readers of Levinas will immediately notice that most of Puntel's criticisms come down to the genuine problems in Totality and Infinity already treated in Derrida's Violence and Metaphysics. Succinctly put: Levinas engages in performative contradiction in using ontological language and traditional conceptuality to speak about that which putatively lies beyond ontology. Puntel is very successful in underlining the various paradoxes this generates throughout Levinas' presentation. If Puntel's criticism were restricted to logical or structural problems in Levinas' texts, there would be nothing more to say. But Puntel also claims that Levinas' ethics and the meaning of God it traces is a mere "function of human subjectivity" (284). This claim, of course, is utter nonsense. Levinas rather functions here as a 'stand in' or better, straw man - for 'postmodern' approaches to God in general. Puntel writes:

the God [the 'postmodernists'] in one way or another arrive at - if the [unknowable] X they arrive at deserves the name "God" at all - is the Other, the absolute Other, the absolutely Distant, or the like. But this "God" proves in the last analysis to be nothing other than a function of human subjectivity. If [I] decided to use the language most postmodernist philosophers and theologians employ when they criticize metaphysically oriented philosophies and theologies, [I] would have to say that their God is an idol. But [I] opt not to employ such language, so says instead that no postmodern "God" is the genuine, divine God.

283

Puntel is turning the tables on his 'post-modern' antagonists. This is all well and fine, but we are within are rights to ask: what precisely makes a god 'genuine'? His answer is not hard to surmise, he explicitly writes: "The primordial, universal, maximal dimension of Being is of course thought, but it is thought as encompassing both the dimension of thinking and that dimension's objective counterpole" (208). God is a 'genuine' God because God thinks, and specifically: thinks human beings who think and the totality of what they think. Such a notion was already pregnant in his classification of 'inadequate' approaches to God in the opening chapter, approaches that fail because they are either "unsystematic," "partially systematic," and "antisystematic." Not merely thought but absolutely systematic thought is what makes a god genuinely God. Puntel already comes equipped with a god so construed, and as such his criticisms of Levinas are for the most part completely external. Puntel offers no substantive comments on Levinas' work subsequent to Totality and Infinity, but treats his entire corpus as if it were all of a piece. He does not read Levinas seriously and 
fails to genuinely confront the problems that Levinas sought to diagnose and overcome. This is tragic, as we are about to witness.

The performative contradictions to which Levinas' position is susceptible are not unique to Levinas, as if he were the "deeply confused" (287) idiot Puntel paints him as. They are in fact an abiding problem for any thinking that attends to what's most fundamental, including Puntel's own thought. This can render Levinas and others, for example, Heidegger, but also Puntel, extremely susceptible to parody. For example, when Puntel writes, "The level that includes semantic vocabulary is thus the level on which language is self-determinative. By means of semantic vocabulary items, language determines itself" (171). Since Puntel's whole wager consists in bestowing 'semantic vocabulary items' with ontological import, which is fancy way of saying: bestowing logic with ontological import, languages' self-determination is not merely a formal determination, but Being's own self-determination. As such, "The mind's questions are Being's questions - and vice versa" (220). And given his above contentions that "The subject term is itself just such a complex [semantic] configuration," we must conclude that Puntel has not written this 400-page book, but Being itself has written it. Puntel has not proposed these arguments, but rather "It's writing" or "It's Puntelizing," etc. As such, not Puntel but Being itself through Puntel is engaging in the following performative contradictions.

"Theories," Puntel asserts, "are completely objective in that they are articulated in total independence of subjective attitudes" (157). Nevertheless, Puntel also insists, "Knowledge is a certain kind of attitude of subjects toward reality: this attitude is often called veritative (related to truth) ..." (288). Specifically, 'knowledge' dawns in the form 'it is the case that .... "What" he continues, "is highly significant about this articulation is that it contains no reference whatsoever to any subject or to any subjective factor" (288). Yet, we are also told, "the absolutely necessary dimension of Being is absolutely necessary minded Being, whereby being minded involves intelligence, will, and freedom. ... For this reason, one can also rely on currently widely used terms and say, absolutely necessary personal Being ..." (232-233). The neutrality and impersonality that the 'it' would suggest or that Nature exhibits becomes a Person that thinks and wills; the Person that creates by "positing-within-Being ex nihilo sui et subiecti" (389) worldly beings. Of course, Puntel can resolve all these questions through properly locating each statement in his complex theoretical architecture, but what he cannot do is communicate his proposal to those outside his theory outside the standard grammar of sentences. In order that God be neither subject nor object, God must be the condition for their division. God cannot speak as God, or as traditional religions and theologies regard him to speak, he must rather manifest in the bare 'it' of a logic of truth and as an impersonal medium 
of intelligibility. God is not $a$ being, here, but everything (that-is-intelligible), or in other words: nothing (specific) at all: that which allows beings to signify as beings. Let us call this Godı. Puntel rejects God, and insists that God, as Being as such and as a whole, also does the sorts of things subjects do: thinks, wills, and creates. Let us call this God2. Puntel distinguishes God2 from human subjects by positing God2's uniqueness: God thinks, wills, and creates absolutely. But God2 can only acquire this uniqueness after "reference ... [to God as] subject" or as an ultimate "subjective factor." (288) In order to speak about or thematize God at all, God must be a subject (and object). Puntel must assert that God1 is neither subject nor object so that God2 can be both subject and object. Hence, the theist that questions whether she needs anything like Puntel's ontology to 'understand' or relate to God will be patted on the head: "you let grammar bewitch you." Hence, the atheist that insists that Puntel is loading the game by identifying thought and being at the outset will be charged with irrationalism: "To declare in advance that such theorization is futile would be a dogmatic abdication" (194). And since it is indeed "absolutely senseless" (193) to question whether Necessary Being 'really' exists, what can one do? It is apparently "dogmatic" to question that, which, by definition, cannot be questioned, or in other words: its dogmatic to question dogma.

Clearly, it's not God making such arguments through Puntel, the argument is Puntel's own. Atheists and theists alike will simply reject Puntel's highrationalism and underline how he rigs the game at the outset. Many theists do in fact affirm a God that resembles Puntel's, but they don't try to pull off the slight-of-hand Puntel performs in this book. That is why theists talk alot about stuff like faith and responsibility these days. Puntel completely subjects ordinary language and pragmatics to his authoritarian semantics; he ultimately hands himself the entirety of existence as fodder for theory while couching it all as the sheer necessity of Being's own movement. As Levinas in fact questioned: is "The primordial, universal, maximal dimension of Being ... of course thought" (208)? Indeed, if authentic theory

wholly exclude[s] ... conceptions of philosophy as therapy ..., all forms of philosophy that have practical aims (philosophy as wisdom, as practical reflection, as educational technique, as a way of life, as a way of shaping one's life or orienting oneself with respect to life, as education, etc.), as diagnostic activity, etc.

146

why should we care what that theory has to say? Why does it matter whether the word 'G-d' should signify or not as Puntel wants it to? Unless Puntel can 
answer this question and give a convincing account of the relation of theory to ordinary language - or of God to the world beyond thought - few will care what he has to say. Like Kierkegaard's Hegel, he builds a beautiful conceptual edifice that cannot speak to our world.

In truth, I have perhaps been somewhat harsh in my treatment of Puntel. Puntel's work is in fact a creative and an original piece of philosophical theory. I have been combative in this review because, judging from this book alone, Puntel appears to care little about the genuine challenge that much contemporary philosophy wrestles with; a challenge that defined Levinas' corpus. This challenge is perhaps best spoken in the words of the Hebrew prophet: "to do justice, love mercy, and walk humbly with your God" (Micah 6:8). In the face of the untold horrors of human history, claims that "The primordial, universal, maximal dimension of Being is of course thought" (208) are simply offensive. For theists, God indeed does signify or speak to human subjects: God calls them to responsibility. The God monotheist's worship signify first, not as an absolutely systematic thinking, but as a God who cares and comes to bear on a world as responsibility, love, and justice. We are first of all grasped by a primordially ethical meaning before the necessary theoretical work of thinking through its various entailments. Human thought is not merely Being's thought writ small. And the criteria by which we judge whether the monotheist stands in fidelity to this meaning is the justice with which he or she treats 'ontological' enemies. The mere logic of indicative sentences does not ineluctably coerce our atheist comrades to affirm the monotheist God. Nor Buddhists, Daoists, Pagans, or any other non-theist we can think of. We all retain our right to question because we all do not only signify as instances of Puntel's Being. Theist and non-theist alike can and must question for a just world.

If Puntel had sincerely read and tarried with Levinas, he perhaps could have undertaken his own genuinely interesting and creative project in a more convincing way. Levinas' work has many problems, but the priority of 'pragmatics' to semantics - or of the imperative to the indicative - is not among them. Heidegger, Levinas, and Marion speak to us because the 'Other' that signifies in their work is not the formal "configuration of all configurations," but a living Being and/or God that precedes and exceeds any form or structure, which is just to say: signifies in and as a surplus that exceeds the necessary yet subsequent formal determinations inevitably involved in thinking and transforming the world. This surplus involves an indeterminacy Puntel ultimately finds distasteful, but it nevertheless is apt to world constituted by multiple and incommensurable ontological regimes. Does the redemption of the world require assent to an absolutely all-encompassing and systematic thought? Or does it require living a difficult yet joyous chosenness? Does fidelity to a "genuinely divine God" 
(283) consist in merely thinking all that 'necessarily' is, or does it perhaps involve performing the affirmative self-emptying an irreducibly messy and uneven world solicits? Performing the pardon, giving, suffering, struggle, and joy of the God of the Book(s), or performing a Total Thought? Puntel's God or Levinas'? This is the choice Puntel foists upon us, perhaps needlessly. 